\title{
From varieties in contact to the selection of linguistic resources in multilingual settings
}

Isabelle Léglise (CNRS, SeDyL) \& Santiago Sánchez Moreano (Université Paris 3 Sorbonne Nouvelle, SeDyL)

This chapter focusses on various methodologies we can rely on to study heterogeneity and dialectal variation among multilingual speakers. We first focus on linguistic variation in contact settings and present a methodology to describe heterogeneous and multilingual corpora and show how languages sometimes overlap. A second part focusses on (dialectal) language boundaries and how speakers may sometimes use unmarked elements showing fuzziness or reorganization of language boundaries. The role of ideology is highlighted in discourse but also at play in language practices and in doing-being 'multilingual', 'urban and modern' or performing authenticity. The third part focusses on how speakers use dialectal and linguistic resources from their linguistic repertoire in their everyday life interactions as stances and acts of identity.

1) Variation in multilingual settings

Although we know societal multilingualism is the norm and monolingualism is the exception, a special case, linguistic description, from the 16th century onwards, focused on languages or dialects (in fact a language or a dialect at a time) by forgetting the multilingual environment of the speakers. The "persistent use of language as a synecdoche for community" (Gal \& Irvine 1995, 968) relies on a pervasive ideology: to consider languages as spoken within monolingual and monocultural communities. This ideological construct is still very lively although it was criticized 50 years ago because it leaves on the side questions of variation, multilingualism, and social construction of language (Hymes 1967). So we should conceptualize communities as imagined entities, or imagined communities (Anderson 2006).

Sociolinguistic research on variation has also mostly focused on monolingual population even if variationists knew the speech communities under consideration were heterogeneous and socially and linguistically diverse. The pioneering studies on social stratification in New York (Labov 1966, 1972) or social differentiation of English in Norwich (Trudgill 1974) excluded for example non-native speakers and focused on intra-varietal change (Labov 1994: 20). But communication ordinarily takes place not in monolingual linguistic communities perceived as homogeneous, but in a multilingual "contact zone" (Pratt 1991). Research on multilingualism and code-switching (Fishman 1967; Gumperz 1982; Myers-Scotton 1993; Auer 1998; Muysken 2000 among others) took this multilingual contact zone seriously. But it has been difficult to integrate the 
results of these different lines of research, perhaps because it is widely assumed that the "variability found in bi- and multilingual speech communities is more extensive than that found in monolingual and majority-language communities" (Sankoff 2002: 640)? There is still a relative lack of published research on variation in multilingual settings (but see for eg. Meyerhoff \& Nagy 2008 or Léglise \& Chamoreau 2013), except in the sub-field of dialects in contact (Gumperz 1958; Trudgill 1986; Siegel 1987; Mesthrie 1993; Kerswill \& Williams 2000; Auer, Hinskens \& Kerswill 2005, etc.).

Most studies in contact linguistics and code-switching nevertheless assumed also languages as discrete and bounded systems in contact, and terms as matrix language or code-alternation are good examples of this hypothesis (Léglise 2017). A shift in focus can be noticed within the last decade, from how bounded communities come into contact and with what kind of linguistic outcomes, to how social actors produce and negotiate social meanings, social positions and relations through their language practices. Within the scope of multilingualism, lots of terms were coined the last 10 years to give a voice to this heterogeneity such as crossing (Rampton 2005), trans-idiomatic practices (Jacquemet 2005), translanguaging (Garcia 2009, Garcia \& Li 2013, Creese \& Blackledge 2010) or (poly)languaging (Jørgensen et al 2011). Hall \& Nilep (2015), in their review on 40 years of research on codeswitching, show very clearly how contemporary research, much centered on linguistic repertoires, wonderfully illustrates disruption of presumed connections between language, community, identity and spaces. This has of course an impact on how to deal with linguistic variation in multilingual settings, and the three sociolinguistic waves (Eckert 2012) took also the same way in monolingual environments, from the analysis of varieties of global communities to communities of practices and to individuals' practices.

In this paper we will address language variation as a linguistic resource in multilingual, heterogeneous language practices and look at what kind of methodology we can rely on. In the first part, we will focus on language tagging in plurilingual heterogeneous corpora before getting to two case studies: language practices among Maroons in French Guiana, and with Kichwas in Cali, Colombia. We will consider how social actors make use of their linguistic repertoire to communicate - to what purpose and with what kind of construction of social meaning - instead of looking at the consequences of their "dialects in contact"1.

\section{2) Methods for analyzing variation in heterogeneous corpora}

Following the French tradition in sociology of language and sociolinguistics, we consider language practices as social practices. Pratiques langagières is a term coined 40 years ago to insist on the fact that language practices are determined and constraint by social order and at the same time construct social meaning, produce social effects and contribute to change it (Boutet, Fiala \& Simonin 1976). Social practices, social formations and symbolic power are to be understood here through a theory of practice

\footnotetext{
${ }^{1}$ For such an analysis, we refer the reader to Léglise (2013) for the consequences of contact between French and Creole, Migge \& Léglise (2013) for varieties of English-based Creoles in contact and Sanchez Moreano (2015) for the consequences of contact of Quichua on Spanish.
} 
such as the one of Bourdieu (1977). In a multilingual environment, these language practices are heterogeneous (Léglise 2013) in the sense that they are made of linguistic resources attributable to various sources and due to the diverse linguistic repertoires of the languagers. Languaging may constitute a good translation. As Jørgensen (2011) puts it: "[a languaging perspective] emphasises that people do not primarily use 'a language', or 'some languages', but use language, linguistic resources."

To describe precisely the linguistic made-up of these language practices, a methodology has been developed through various research programs ${ }^{2}$. We use the term "plurilingual corpora" to designate the heterogeneous corpora we created based on heterogeneous language practices (i.e made of resources from multiple languages within the same recordings). They illustrate not only instances of codeswitching and codemixing but also languaging through the use of linguistic bricolage. They are performed by plurilingual speakers with varied skills, competence and diverse repertoires (Blommaert \& Backus 2011). They also exhibit variation and non-standard forms, often neglected by monolingual corpora, or controlled for by general parameters (such as the types of speech). These plurilingual corpora are still few in number, not readily available to the linguists' community, and rarely "processed" by the available computer software. They pose formidable problems, not only of the identification of forms but also of their transcription and annotation.

In corpus linguistics, the Text Encoding Initiative (TEI) proposes a set of standards for annotating corpora. We refer the reader to Vaillant and Léglise (2014) for technical details on the annotation system established but would like to mention a major adaptation for heterogeneous corpora. The TEI recommends identifying the basic language of each sentence, and noting in angle brackets when an item from another language is introduced, for instance as $<$ foreign item belonging to language $x>$. A first problem, when faced to heterogeneous practices, is that the systematic allocation of one basic language for each speech turn is not possible (see Léglise \& Alby (2016) for a discussion). In most cases, we observe several linguistic resources in the same speech turn produced by the same speaker. For example, in (1), a client is addressing an employee of the national electricity company, in Cayenne, French Guiana ; the first line can be attribute to Créole guyanais (a French-based Creole), the second line seems to begin in Creole and to end in French, whereas the third line seems to begin in French and to end in Creole. Here, bold stands for Créole guyanais, roman for French and italics+bold are for Antillan Creole insertions.

\footnotetext{
2 The methodology was developed within the CLAPOTY project, funded from 2009 to 2014 by the ANR under the number 09-JCJC-0121-01 and further tested within the Language Contact program funded by the French Investissements d'Avenir - Labex EFL program (ANR-10-LABX-0083) whose PI was I. Léglise.
} 
(1) Corpus EDF Clapoty - Nelson / Léglise ${ }^{3}$

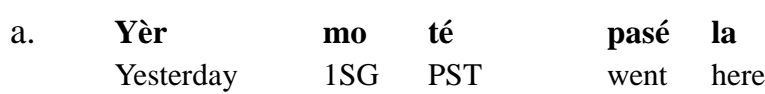
Yesterday I was here

\begin{tabular}{ll}
\hline b. & $\mathrm{i} \quad$ té $\quad$ gen an $:: \quad$ madame un peu \\
\hline & 3SG TE.PST have ART.INDF misses a little. ADV \\
& There was $a::$ woman a little bit sturdy just here
\end{tabular}

\begin{tabular}{llll|}
\hline c. & costaud & à côté & là \\
\hline & sturdy & next to. ADV & here.ADV \\
& sturdy just here
\end{tabular}

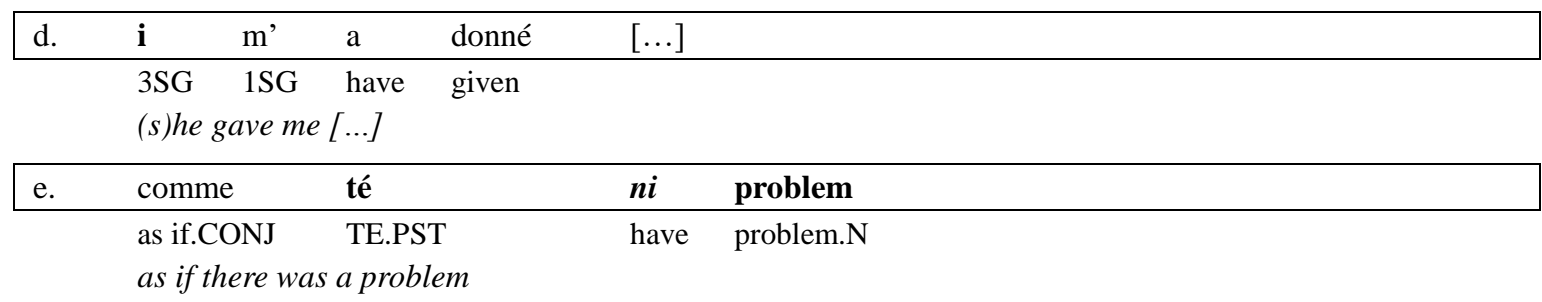

Rather than selecting - often arbitrarily - one language as the matrix language (MyersScotton 1993b, see Nunez \& Léglise 2017 for a discussion), we propose to consider that the utterance is multilingual and we represent this visually here by a frame. We, then, identify elements assignable to a particular language within each multilingual turn.

A second problem, when faced to heterogeneous practices, is that many elements can be attributed to various languages. For example, in (1), $i$ at the beginning of the third line can be both interpreted as third person singular pronoun in spoken French (classical pronunciation of $i$ for $i l$ ) or in Creole (being Créole guyanais or Créole antillais). These homophonous diamorphs or bivalent elements have been long identified in the literature on code-switching (Muysken 1990, Woolard 1998) but never treated as such in corpus linguistics. We follow here the proposition of Ledegen (2012) to adopt a double or floating transcription in order to show the various possible interpretations, so the third line would offer the following possibilities:

\begin{tabular}{|c|c|c|c|c|c|c|c|c|c|}
\hline c. & $\begin{array}{l}\boldsymbol{i} \\
\mathbf{i} \\
\mathrm{i}(\mathrm{il})\end{array}$ & m' & $\mathrm{a}$ & donné & {$[\ldots]$} & comme & $\begin{array}{l}\text { té } \\
\text { té }\end{array}$ & $n i$ & $\begin{array}{l}\text { problème } \\
\text { problem } \\
\text { problem }\end{array}$ \\
\hline & $\begin{array}{l}\text { 3SG } \\
(s) h e\end{array}$ & $\begin{array}{l}1 \mathrm{SG} \\
\text { ave } \mathrm{m}\end{array}$ & $\begin{array}{l}\text { have } \\
{[\ldots]}\end{array}$ & given & & $\begin{array}{l}\text { as if.CONJ } \\
\text { as if there }\end{array}$ & $\begin{array}{c}\text { TE.PST } \\
\text { was a pro }\end{array}$ & have & problem.N \\
\hline
\end{tabular}

We see clearly here how languages sometimes overlap and imagine what it could imply for the study of linguistic variation.

\footnotetext{
${ }^{3}$ The recording and first transcript comes from Nelson (2008). Annotation was done through the Clapoty project.
} 
3) (Un)marking dialectal language boundaries

As a first case study, we will focus now on the Maroon people in French Guiana who speak 3 related English-lexified Creoles that originally emerged on the plantations of Suriname, namely Aluku, Ndyuka and Pamaka. These languages are associated with three independent Maroon communities bearing the same names and residing in French Guiana, especially along the Maroni River, for more than two centuries or are recent migrants from the interior of Suriname. Based on sociohistorical and comparative linguistic data, linguists argue that they are dialects of a common language called Nenge(e), Businengetongo or Eastern Maroon Creole (Migge 2003, Goury \& Migge 2003).

They may also speak Sranan Tongo, the mother tongue of the descendants of slaves who did not flee the plantations of Suriname. Sranan Tongo also serves as a lingua franca in multiethnic Suriname and is the language of the urban population (Carlin \& al 2015). Although all these 4 English-based Creoles descend from the same plantation varieties, they differ somewhat linguistically and are not fully mutually intelligible due to partially different linguistic developments. For example urban varieties of Sranan Tongo have been subject to relatively strong influence from Dutch.

Over the last 20 years, mobility to urban contexts has led to an expansion of the linguistic repertoires of the population which are now more diverse or heterogeneous. Maroons had to acquire some competence in the regional lingua franca Sranan Tongo or in Créole guyanais and French, the official language, to interact with the members of the other local populations. The expansion of the linguistic repertoire has also led to changes in individual and community language practices so we find a greater use of Sranan Tongo in in-group encounters. On the coast where the members of the different Maroon groups are now in regular contact with each other and with members from other local social groups (e.g. Haitians, Amerindians, Créole guyanais, metropolitain French), Maroons have develop a different sense of ethnic belonging. Unlike previous generations of Maroons who generally emphasized inter-Maroon differences, they now emphasize the similarities that exist between the different Maroon groups. It is linked to a new pan-Maroon identity that transcends the traditional ethnic divisions.

While interested in the emergence of language varieties (Migge \& Léglise 2011), we showed that this process of identity formation was giving rise to processes associated with koineization (i.e. involving mixing of features from different related regional dialects, levelling of such features, formal reduction, and finally focusing of a new 'mixed' variety (Siegel 1985). Dialect mixing involving Sranan Tongo and the Maroon varieties is now widespread even in in-group encounters. We also found processes of leveling in progress. For example, ethnically marked morphosyntactic features such as the verbal negation marker (á (Ndyuka), án (Pamaka/Aluku)) and the negative potential marker (man (Pamaka, Aluku), poi (Ndyuka)) were replaced with more ethnically neutral equivalents that usually come from Sranan Tongo, namely no and kan.

Using the method we developed in-between has made possible to show that in some corpora almost all the turns can be attributed to one or the other variety, to one or the other language, as in Example 3 where the discussion between three men in a bar could 
be viewed as either Nenge(e) or Sranan Tongo ( 9 elements could be both, and 4 from Sranan).

(3) Discussion between men in a bar in Saint-Laurent (corpus CLAPOTY_Migge)

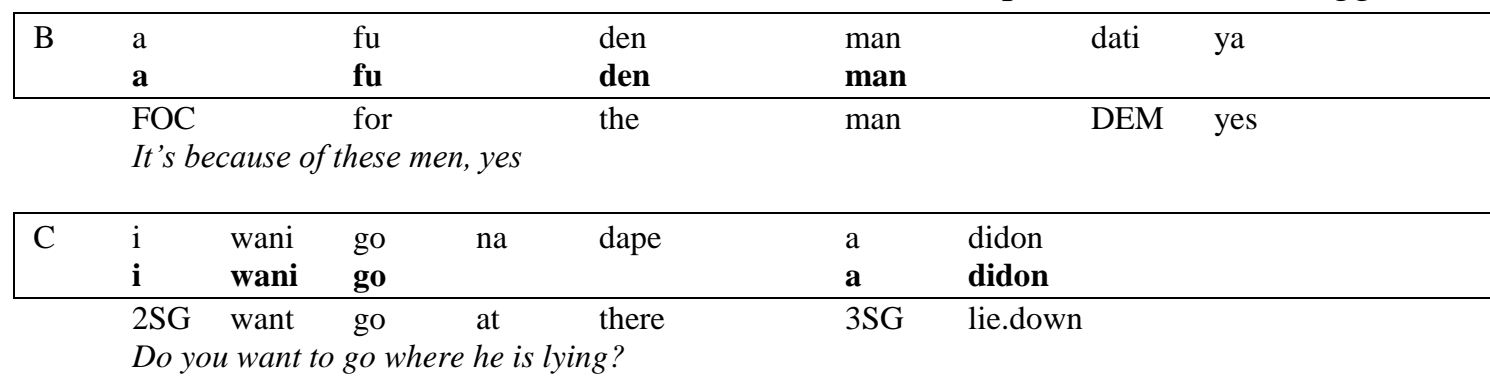

Our deliberate choice to present all the possibilities in the transcriptions transforms the way we look at the corpora. Rather than viewing extract (3) as spoken in Nenge(e) with some inserted items of Sranan Tongo (Migge and Léglise 2011), we can conclude that the speakers prefer to use items common to both languages to express themselves. In doing so, they use bivalent, unmarked elements showing fuzziness or a form of reorganization of language boundaries (Léglise 2017). They may signal the fuzziness also expressed by the name they can put on it, takitaki, a useful label (Migge \& Léglise 2013) which avoids reference to ethnic identification (Pamaka, Ndyuka, Aluku), language names and boundaries such as Nenge(e) vs. Sranan Tongo. Because language denominations and categorizations are always situated, takitaki offers a useful fuzziness to express homogeneity or differentiate ways of speaking when necessary ("this is all the same language" vs. "there are different kinds of takitaki").

But, at times, people select, meaningfully a particular and iconic feature from their linguistic repertoire to signal differences. For example, in urban settings young people generally employ a form of code-switching with Sranan Tongo to construct themselves as sophisticated and urbanized Maroons and code-mixing to assert membership in the social group of young men whose salient properties are modern urban sophistication (Migge 2007, Migge \& Léglise 2013). They may also include linguistic resources from other languages (such as Dutch, English or French) in a way of doing-being multilingual, urban and modern to differentiate from more traditional ways of speaking linked to rural area.

4) Linguistic resources as stances and acts of identity

Our second case study focusses on how speakers use dialectal and linguistic resources from their linguistic repertoire in their everyday life interactions as stances and acts of identity. Examples here are taken from features from several varieties of Spanish spoken by Quichuas in Cali, Colombia. Cali is the third largest city in Colombia with more than two million people including indigenous $(0.55 \%)$ and afrocolombian $(26.95 \%)$ minorities. A $71.56 \%$ of people are self -recognized as non-ethnic, i.e. metis and white people. Although this seems to be a clear and steady image for Colombian Administrative Department for Statistics (DANE, 2005) ${ }^{4}$, the heterogeneity of Cali's populations seems to be more complex and dynamic if we look at it through an

\footnotetext{
${ }^{4}$ Departamento Administrativo Nacional de Estadística, 2005.
} 
ethnographic perspective. Indigenous populations, for example, in most of the cases, have been forced by social, economic, and security factors to leave their original territories to look for better life conditions in the cities. In the cities, they are socially organized and recognized by local and national authorities. They constitute Cabildos urbanos, a sort of institutional and administrative forms of organization for indigenous populations in urban settings. One of these groups is the Ecuadorian Kichwas who come from two different regions in Ecuador: Imbabura and Chimborazo (Map 1). 


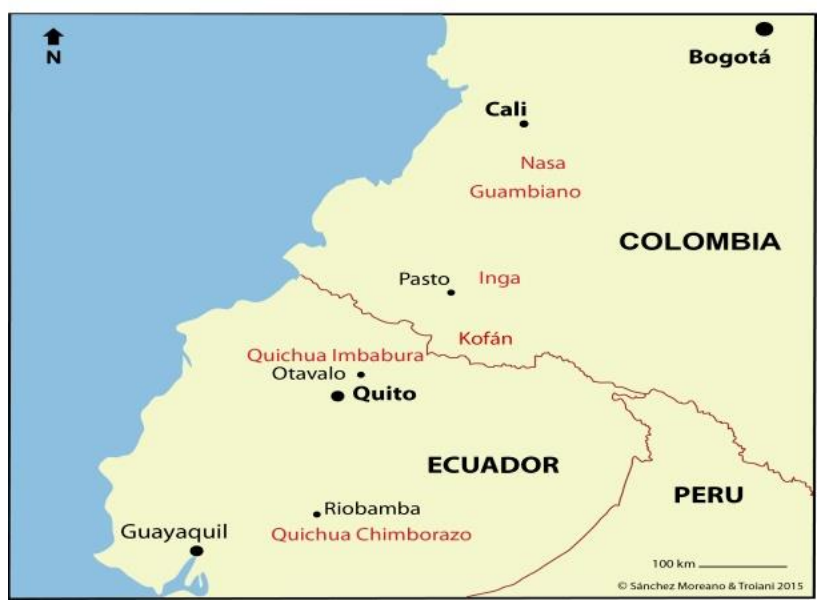

They live in Cali since the sixties and today, at least two generations have been born in the city. Most of them work in the downtown streets selling hand-made products and traditional clothes, as well as other manufactured products. Their labor informal activities lead them to interact constantly with the local retailers and with the other indigenous groups. The estimated number of Kichwas in Cali is 376 people, gathered in 90 families (Anacona, Cardona, and Tunubala 2012). The asymmetrical contact of populations in Cali results in a multi-ethnic and multicultural environment shaped by different dynamic social variables such as ethnicity, mobility, transnational migration, integration to the economic and social life, and language practices. This complex social situation has important sociolinguistic consequences which entails, for example, the use of specific linguistic forms drawn on speaker's linguistic repertoires.

Kichwas in Cali speak the Ecuadorian varieties of Andean Spanish (AS), a broader Spanish variety largely described in the literature as being influenced by Quichua and Aymara languages (Haboud 1998; Merma Molina 2008; Palacios Alcaine 2005b; 2013; Adelaar and Muysken 2004; Muntendam 2013; Pfänder 2009). AS has its own characteristics which make it different from other Spanish varieties. One of these features is the high frequency of OV syntactic constructions, the vocalic system reduction, the simplification of pronoun system, and the particular use of gerunds, among others. Kichwas also adopt and use linguistic forms of Caleño Spanish (CS), the local Spanish variety, less known in the literature ${ }^{5}$ but making part of the Colombian Spanish described by some studies in dialectology (Montes 1992; Flórez 1961; Patiño 2000; Mora 1996). Probably, CS's most salient feature is the well described phonetic reduction of /s/ (Brown and Brown 2012; Ramírez Espinoza and Almira Vazquez $(2016)^{6}$.

They also speak Imbabura Quichwa (IQ) and Chimborazo Quichua (CHQ), two varieties of Andean Highlands Quichua ${ }^{7}$. However, a language shift situation (Thomason and Kaufman 1988), favored by the local Spanish hegemony, is observed in this context. These Quichua varieties are relatively well-known in the literature, although they may be considered as non-standard varieties ${ }^{8}$. Interestingly, these two varieties may serve as a means for indicating difference between Kichwas from Imbabura and Chimborazo.

\footnotetext{
5 Varieties of Spanish spoken in Bogotá, Medellín, Barranquilla, Valledupar, for example, are being studied within variationist projects such as the Proyecto para el estudio sociolingüístico del español de España y de América (http://preseea.linguas.net/).

${ }^{6}$ Phoneme /s/ reduction is a characteristic feature of several varieties of spoken Spanish in America and Spain (Brown and Brown 2012,89). It is a wide-spread and well-known phonological phenomenon in Spanish linguistics (Lipski 1984).

${ }^{7}$ From the northern branch of the Quechua family

${ }^{8}$ For there are no studies of these varieties in contact with Spanish in urban settings in Colombia,
} 
The fact that AS and CS but also IQ and CHQ have come into contact due to the Kichwas' transnational migration to Cali has at least two consequences: 1) their linguistic repertoires have become heterogeneous; and 2) their language practices are heterogeneous and show evidence of phenomena that can be describe as codeswitching, dialect-switching, languaging and other (contact-induced) linguistic variations at various (phonetic, morphosyntactic, interactional) levels. We believe that the choice of one specific linguistic marked form within conversations is socially meaningful as we will show below. As for the annotation, we decided to annotate as unmarked Spanish the forms with no particular specificity. For example, in (4) the speaker uses buenas, a form of unmarked Spanish (A). Then he uses a linguistic form attributable both to Caleño Spanish (B), or to Andean Spanish (C). In fact, it may belong to C (Andean Spanish) as we observe the lengthening of the vowel /a/ and the Ecuadorian phonetic variant [ $]$. These two elements are phonetic characteristics of Equadorian Andean Spanish. This element may also belong to B (Caleño Spanish) since we can observe the reduction of phoneme /s/. Whereas si in (5) is the only element unequivocally marked as Caleño Spanish [B] because of its pronunciation.

$\mathrm{AB}$

$\mathrm{C}$

$\begin{array}{ll} & \text { ['ta::deh] } \\ \text { buenas } & \text { ['ta:::[de] } \\ \text { good } & \text { afternoon } \\ \text { ADJ } & \mathrm{N} \\ \text { Good afternoon }\end{array}$

\begin{tabular}{|c|c|c|c|c|c|}
\hline \multirow[t]{5}{*}{$\mathrm{ABC}[\mathrm{B}]$} & $\underline{s i}$ & va & quedar & conmigo & \\
\hline & si & va & quedar & conmigo & \\
\hline & si & va & quedar & conmigo & si [ $\left.{ }^{\mathbf{i}} \mathbf{i}\right]$ (laughing) \\
\hline & yes & go.3SG & stay.INF & with.PREP;1SG DAT & yes \\
\hline & ADV & V & $\mathrm{V}$ & ADP;PRN & ADV \\
\hline
\end{tabular}

For the purpose of the exposition, in the case of $\mathrm{ABC}$, in (5), we may indicate below only A for unmarked. And finally, we may label a whole turn as an instance of a particular variety, as in (6) where the word order (OV) and the use of the discursive maker nomás ${ }^{9}$ are criteria to label the turn as Andean Spanish.

(6)

$\begin{array}{lllll}\text { C } & \text { puro } & \text { Español } & \underline{\text { nomás }} & \underline{\text { habla }} \\ & \text { pure } & \text { Spanish } & \text { only } & \text { speak.3SG } \\ \text { DET } & \text { N } & \text { ADV } & \text { V }\end{array}$

Pure Spanish only she speaks

Example (7) shows how a speaker, as a social actor, makes linguistic choices to express brief affiliation. $\mathrm{M}$ is a Kichwa old lady working down-town. She spends her worktime with other colleagues who may be indigenous, afrocolombian or non-ethnic. $\mathrm{C}$ is a nonethnic Caleño who asks M, in the first turn, to keep an eye on his stuff (001). He uses undeniably forms of Caleño Spanish. Interestingly, $\mathrm{M}$ answers affirmatively to his request using a Quichuan affirmative adverb ari in the second turn (002). C recognizes

\footnotetext{
${ }^{9}$ Nomás in Andean Spanish would be influenced by the enclitic prefix -lla from Quichua (CerrónPalomino 2003, 193).
} 
this element as Quichua and replies introducing in the third turn (003) a linguistic form of Quichua: shuhuas (thieves). Then M replies again using Quichua (004).

(7)

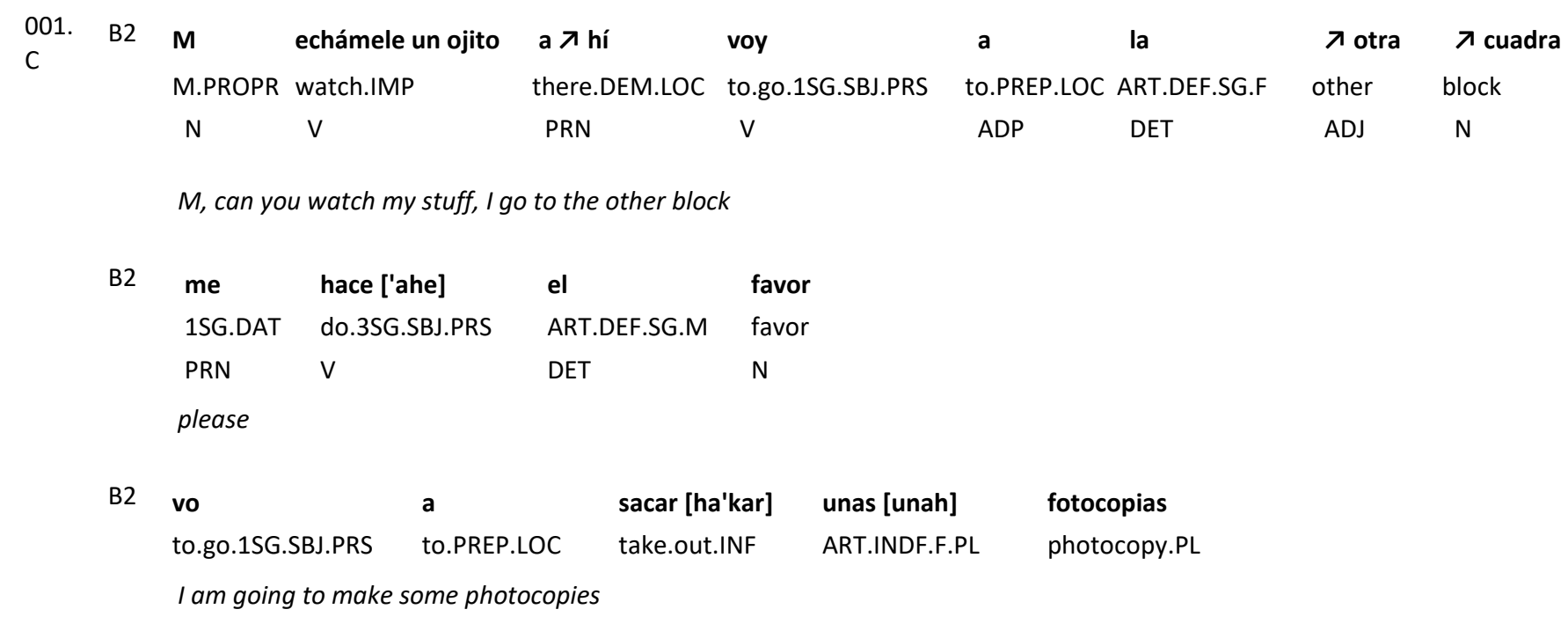

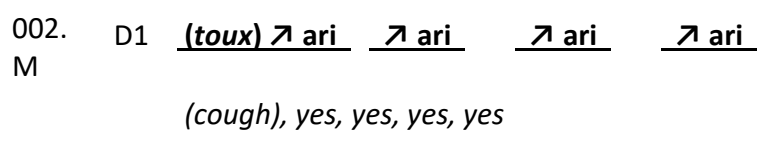

\begin{tabular}{|c|c|c|c|c|c|}
\hline \multirow[t]{3}{*}{$\mathrm{BDC2}$} & ojo & con & los ['loh] & $\begin{array}{l}\text { chugua-s ['tuwah] } \\
\text { shuhua-s ['tuwah] }\end{array}$ & ahí \\
\hline & eye & with.PREP.ASSOC & ART.DEF.M.PL & thief-PL & there.DEM.LOC \\
\hline & $\mathrm{N}$ & ADP & DET & $\mathrm{N}$ & PRN \\
\hline & watch o & ves! & & & \\
\hline $\begin{array}{l}\text { 004. D1 } \\
\text { M }\end{array}$ & $a \pi r i$ & & & & \\
\hline
\end{tabular}

Following Auer (1995) interactional annotation ${ }^{10}$, we observe the pattern B2 D1 BCD2 D1: it means C starts using Caleño Spanish, while M follows in Quichua. In 003, C uses not only forms of Caleño Spanish, but selects a specific form which may be construed as Quichua (D) or Andean Spanish (C), two language varieties spoken by M. He shows he is able to understand the forms of Quichua introduced by $\mathrm{M}$ and to use a term that was not supposed to belong to his linguistic repertoire (he is supposed to only speak Caleño Spanish).

This sequence also shows the interesting use of the term ['fuwah], shuhua in Quichua. First, ['fuwah] shows evidence of phonetic variation as a consequence of the appropriation $\mathrm{C}$ makes of it. In fact, $\mathrm{C}$ produces the original Quichua word ['Juwah], as a voiceless palato-alveolar affricate $[\mathfrak{t}]$, the common realization of the written letters "ch" in Spanish. Moreover, he produces a final /s/ reduction, i.e., /s/ aspiration. ['fuwah] means "thief" or "thieves" and it is usually used among Kichwas to alert the others about the presence of a thief nearby, without the thief himself realizing it. The fact that $C$ uses it shows evidence of his strategy for convincing $M$ to keep an eye on his stuff while he goes momentarily away. It may also be considered as a way of expressing a social position of brief affiliation to the Kichwas group in order to support his request, which can be considered as a search for solidarity among retail traders.

\footnotetext{
${ }^{10}$ Where (varieties of) languages are coded with letters and interlocutors with numbers.
} 
Example (8) also shows the use of a specific linguistic feature from one of the Spanish varieties in contact in Cali. $\mathrm{M}$ is a kichwan old lady speaking Andean Spanish and Quichua. T is a caleño speaker who is talking to L, her niece, a 10 year-old girl. She says to $L$ that she should stay with $M$ to learn Quichua. But, before L answers, M replies for her using an affirmative adverb clearly realized as Caleño Spanish. The phonetic transcription shows the reduction of /s/, a well-known feature of Caleño Spanish.

\begin{tabular}{|c|c|c|c|c|c|c|c|c|}
\hline \multirow[t]{3}{*}{ 003. T : B3 } & usted & se & va & a & quedar & aquí & pa & aprender \\
\hline & 2SG.SBJ & 3SG.REFL & go.3SG.SBJ.PRS & à.PREP & stay.INF & here & to & learn.INF \\
\hline & PRN & PRN & V & ADP & V & ADV & ADP & V \\
\hline & \multicolumn{8}{|c|}{ You are going to stay here to learn } \\
\hline \multirow[t]{4}{*}{ 004.M: B1 } & \multicolumn{8}{|l|}{ sí [’hi] } \\
\hline & \multicolumn{8}{|l|}{ yes } \\
\hline & \multicolumn{8}{|l|}{ ADV } \\
\hline & Yes & & & & & & & \\
\hline
\end{tabular}

This choice is socially meaningful. T uses first Caleño Spanish and is followed by $M$ who uses a specific form of Caleño Spanish. By using it, M expresses an affiliation to the majority group to which $\mathrm{T}$ belongs. This affiliation is the consequence of the asymmetrical contact situation in which Kichwas evolve in Cali. Due to the linguistic ideology which says that Caleño Spanish (as a language spoken by the majority group) benefits of a positive view rather that the Andean Spanish variety spoken by a minority indigenous group, Kichwas tend to align with their interlocutors to express this affiliation.

However, the linguistic choice of an element may also express differentiation or exclusion. For example, in excerpt (9), the use of Andean Spanish shows that $\mathrm{M}$ switches from A to $\mathrm{C}$ after the evaluation that she makes of an element represented in the discourse situation. $\mathrm{S}$ asks $\mathrm{M}$ if $\mathrm{L}$ is her daughter. $\mathrm{M}$ answers negatively. Then $\mathrm{S}$ asks $\mathrm{M}$ if $\mathrm{L}$ speaks Quichua, but $\mathrm{M}$ does not answer this question directly. Rather, she uses a SOV syntactic structure and a restrictive adverb (nomás), both highly frequent in Andean Spanish (004).

(9)

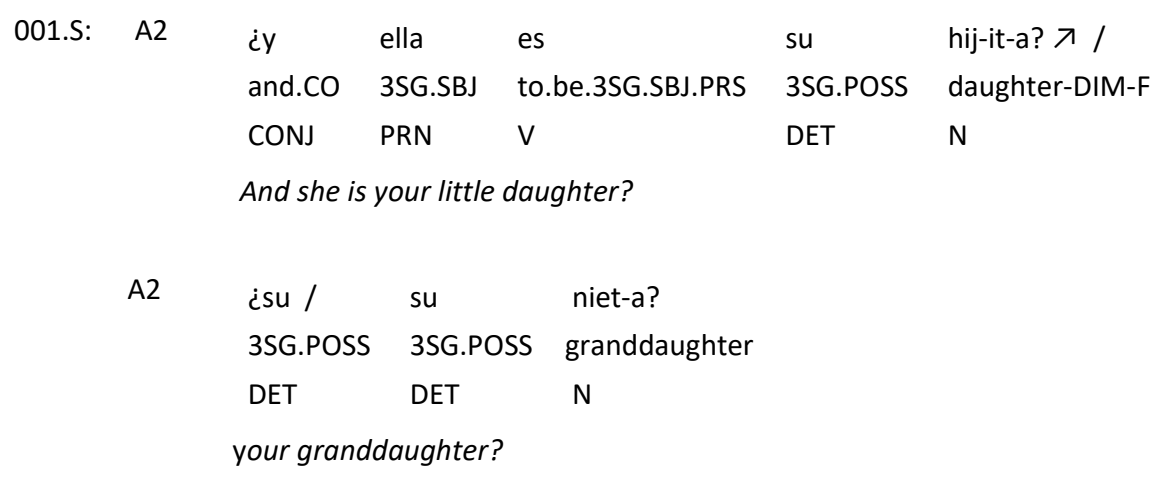

002.M: A2 no

No 
$\begin{array}{lll}\text { 3SG.SBJ } & \text { speak.3SG.SBJ.PRS } & \text { quichua } \\ \text { PRN } & \mathrm{V} & \mathrm{N}\end{array}$

Does she speak quichua?

\begin{tabular}{|c|c|c|c|c|}
\hline \multirow{3}{*}{$\begin{array}{l}004 . \\
\text { M: }\end{array}$} & ella & amig-a $\lambda$ & nomás & es $\searrow$ \\
\hline & 3SG.SBJ & friend-F & only & to.be.3SG.SBJ.PRS \\
\hline & PRN & $\mathrm{N}$ & ADV & V \\
\hline
\end{tabular}

Lit. she friend only is / She is only a friend

By using these forms, M positions herself as a speaker of Andean Spanish, therefore as belonging to the group of Kichwa from Cali, a group to which L does not belong to. By doing this, M excludes L from the groups of Kichwas.

As we may see, the selection of linguistic features is socially meaningful in theses interactions as it entails social implications for speakers within conversation. These choices may construct social positioning expressing brief affiliation and differentiation. However, if we look in depth to the interactional sequences, these social positionings are framed within a broad act of stance. Social identities are linguistically indexed through different related indexical processes that contribute directly or indirectly to the construction of social identities. According to Bucholtz and Hall (2005)'s model for analyzing identity as it emerges in social interaction, these processes may include, among others, displayed evaluative and epistemic orientations to ongoing talk, as well as interactional footings and participant roles. The selection of specific linguistic forms from heterogeneous linguistic repertoires in Cali contributes to the expression of evaluative and epistemic orientations. That is what Ochs (1992) calls "stance", a concept developed by Du Bois (2007) and Kiesling (2011). Stance is an act of social positioning implying an evaluation of an element (stance focus) existing in the discursive context by a social actor (stancetaker). It implies also his positioning vis-à-vis the stance focus and his/her alignment or dis-alignment vis-à-vis another social actor.

The examples discussed above show how a speaker may align or dis-align with his/her interlocutor within conversation through the choice of a specific linguistic form belonging to his/her linguistic repertoire. These (dis-)alignments take part on a single act of stance which includes an evaluation of some element in the communicative environment. This element will determine a positioning by the speaker and then an alignment or dis-alignment shaped on the selection of a linguistic form. For example, in (7), the stance focus is the utterance in 002 produced in Kichwa by speaker 1 . Speaker 2 evaluates this focus and then positions himself as someone being able to use Quichua words to support his requests. This positioning is followed by an alignment with his interlocutor. The whole act is a stance of brief affiliation by the speaker 2 to the group of Kichwas to accomplish his request.

In (8), the stance focus is the fact that $\mathrm{T}$ speaks the prestigious local variety of Spanish. $\mathrm{M}$ evaluates this focus and positions herself as belonging to the majority group by aligning herself with T. By doing so, she leaves behind, momentarily, her own ethnicity to accomplish an act of stance of brief affiliation.

On the contrary, we observed in (9) that the selection of specific linguistic features may also express differentiation and exclusion. In this interaction, the stance focus is the question asked by $\mathrm{S}$ in 003 about the fact that $\mathrm{L}$ speaks Quichua or not (speaking Quichua meaning that she may belong to the group of Kichwas). M evaluates this question and dis-aligns with $\mathrm{S}$. This dis-alignement means that either $\mathrm{S}$ neither $\mathrm{L}$ belong to the group of Kichwas from Cali. 


\section{Conclusion}

Language variation is a linguistic resource in multilingual, heterogeneous language practices. The annotation method we followed reveals the heterogeneity of language practices and at the same time show how languages or varieties sometimes overlap making it irrelevant to draw arbitrary lines and boundaries between linguistic resources. This has a great impact on the way we - as linguist - consider the attribution of language (or variety) labels to linguistic forms.

Language practices among Maroons in French Guiana showed the strong tendency for languagers to use unmarked or bivalent elements that could belong to two or more languages (or language varieties). As language denominations and categorizations are always situated, it has no sense to ask people what they think about the belonging of a form to a language (or language variety): their response may vary as often as the context changes and in relation to the local or more global necessity of affiliation or differentiation. These language practices tell us that using bivalent elements as linguistic resources is a way of showing fuzziness and challenging language boundaries. In this case, it may be a way to assert a pan-Maroon identity (by challenging the varieties boundaries) or a way to perform urbanity and masculinity (by challenging language boundaries).

Language practices with Kichwas in Cali showed that the selection of linguistic features is socially meaningful as it constructs social positioning expressing brief affiliation and differentiation. However, if we look in depth to the interactional sequences, these social positionings are framed within a broad act of stance. These stances observed in social interactions may reveal larger mechanisms of identity construction towards the majority society, and as Kichwas in Cali. At a local level, they confirm that languagers sometimes affiliate with imagined communities (Kichwas or Caleños for example) at their convenience through the selection of specific linguistic forms within their heterogeneous linguistic repertoires, or sometimes show, in purpose, dis-affiliation as ways of differentiation or exclusion. All are illustrations of social meanings and positionnings constructed by language practices.

\section{References}

Adelaar, Willem, and Pieter Muysken. 2004. The Languages of the Andes. Cambridge, New York, Madrid: Cambridge University Press.

Anacona, Adriana, Maria Isabel Cardona, and Mercedes Tunubala. 2012. « Estudio de Caracterización de Pueblos Indígenas: Kofán, Misak -Guámbianos, Quichuas, Ingas, Yanaconas, Nasas habitantes de Santiago de Cali ». Informe de proyecto: « Asistencia Técnica para la Implementación de la Política Pública Indígena en Santiago de Cali ». Cali: Alcaldia de Santiago de Cali.

Anderson, Benedict. 2006. Imagined Communities: Reflections on the Origin And Spread of Nationalism. Revised. Verso Books.

Auer, Peter. 1995. "The pragmatics of code-switching: a sequential approach ». In One speaker, two languages: Cross-Disciplinary Perspectives on Code-Switching, edited by Lesley Milroy and Pieter Muysken, 115-35. Cambridge: Cambridge University Press.

Auer, Peter, ed. 1998. Code-Switching in Conversation. Language, Interaction and Identity. London and New York: Routledge.

Auer, Peter, Frans Hinskens, and Paul Kerswill. 2005. Dialect Change: Converge and Divergence in European Languages. Cambridge: Cambridge University Press. 
Beukema, Ronald William. 1975. "A Grammatical Sketch of Chimborazo Quichua ». Thèse de doctorat, Ann Arbor: Yale University.

Blommaert, Jan, and Ad Backus. 2011. "Repertoires Revisited: 'Knowing Language' in Superdiversity." Working Papers in Urban Language and Literacies 67: 1-26.

Bourdieu, Pierre. 1977. Outline of a Theory of Practice. Cambridge University Press.

Brown, Earl K., and Esther Brown. 2012. "Syllabe-final and Syllabe-initial /s/ Reduction in Cali, Colombia : One Variable or Two? "In Colombian Varieties of Spanish, edited by Richard File-Muriel and Rafael Orozco, 89-106. Madrid; Frankfurt: Iberoamericana ; Vervuert.

Bucholtz, Mary, and Kira Hall. 2005. "Identity and interaction: a sociocultural linguistic approach ». Discourse Studies 7 (4-5): 585-614.

Carlin, Eithne B., Isabelle Léglise, Bettina Migge, and Paul Brendan Tjon Sie Fat, eds. 2014. In and Out of Suriname. Language, Mobility and Identigy. Amsterdam: Brill.

Creese, Angela, and Adrian Blackledge. 2010. "Translanguaging in the Bilingual Classroom: A Pedagogy for Learning and Teaching?" The Modern Language Journal 94 (1): 103-15.

Cerrón-Palomino, Rodolfo. 2003. Castellano andino: aspectos sociolingüísticos, pedagógicos y gramaticales. Lima: Pontifícia Universidad Católica del Perú, Fondo Editorial/Cooperación Técnica Alemana.

DANE, éd. 2008. Censo general 2005: nivel nacional. Colombia: República de Colombia, Departamento Administrativo Nacional de Estadística.

Du Bois, John W. 2007. "The Stance Triangle ". In Stancetaking in Discours, Subjectivity, Evaluation, Interaction, edited by Robert Englebretson, 139-82. Amsterdam / Philadelphia: John Benjamins Publishing Company.

Eckert, Penelope. 2012. "Three Waves of Variation Study: The Emergence of Meaning in the Study of Linguistic Variation." Annual Review of Anthropology, no. 41: 87-100.

Fishman, Joshua A. 1968. "Sociolinguistic Perspective on the Study of Bilingualism." Linguistics 39: 21-49.

Flórez, Luis. 1961. « El Atlas lingüístico-etnografico de Colombia (ALEC): nota informativa ». Thesaurus : boletín del Instituto Caro y Cuervo XVI (1): 77-125.

Gal, Susan, and Judith T. Irvine. 1995. "The Boundaries of Languages and Disciplines : How Ideologies Construct Difference." Social Research 82 (4): 967-1001.

Garcia, O., and L. Wei. 2013. Translanguaging: Language, Bilingualism and Education. 2014 edition. Palgrave Pivot.

Gumperz, John J. 1958. "Dialect Differences and Social Stratification in a North Indian Village." American Anthropologist 60 (4): 668-82.

- - . 1982. Language and Social Identity. Studies in Interactional Sociolinguistics 2. Cambridge: Cambridge University Press.

Gómez Rendón, Jorge. 2007. « Grammatical Borrowing in Imbabura Quichua (Ecuador) ». In Grammatical Borrowing in Cross-Linguistic Perspective, edited by Yaron Matras et Jeanette Sakel. Berlin \& New York: Mouton de Gruyter.

- - . 2008. "Spanish lexical borrowing in Imbabura Quichua: In search of constraints on language contact ». In Hispanisation. The Impact of Spanish on the Lexicon and Grammar of the Indigenous Languages of Austronesia and the Americas, 95-120. Berlin, New York: Mouton de Gruyter.

Haboud, Marleen. 1998. Quichua y Castellano en los Andes Ecuatorianos. Los efectos de un contacto prolongado. Quito: Ediciones Abya-Yala.

Hall, Kira, and Chad Nilep. 2015. "Code-Switching, Identity, and Globalization." In The Handbook of Discourse Analysis, edited by Deborah Tannen, Heidi E. Hamilton, and Deborah Schiffrin, 597-619. Hoboken, NJ, USA: John Wiley \& Sons, Inc.

Hermon, Gabriella. 2001. " Non-Canonically Marked A/S in Imbabura Quechua ». In Noncanonical Marking of Subjects and Objects, edited by Alexandra Y Aikhenvald, Dixon R.M.W, and Onishi Masayuki, 46:149-79. Typological Studies in Language. Amsterdam / Philadelphia: John Benjamins Publishing.

Hurley, Joni Kay. 1995. " The Impact of Quichua on Verb Forms Used in Spanish Requests in Otavalo, Ecuador ». In Spanish in Four Continents : Studies in Language Contact and 
Bilingualism, edited by Carmen Silva-Corvalán, 39-51. Washington DC: Georgetown University Press.

Hymes, Dell. 1967. "Why Linguistics Needs the Sociologist." Social Research 34 (4): 632-47.

Jacquemet, Marco. 2005. "Transidiomatic Practices: Language and Power in the Age of

Globalization." Language \& Communication, Multilingualism and diasporic populationsSpatializing practices, institutional processes, and social hierarchies, 25 (3): 257-77.

Jake, Janice Lynn. 1983. « Grammatical Relations in Imbabura Quechua (Ecuador) ». Phd, University of Illinois at Urbana-Champaign.

Jørgensen, Jens Normann, Martha Sif Karrebaek, Lian Malai Madsen, and Janus Spindler Moller. 2011. "Polylanguaging in Superdiversity." Diversities 13 (2). www.unesco.org/shs/diversities/vol13/issue2/art2.

Kiesling, Scott. F. 2009. "Style as a Stance: Stance as the Explanation for Patterns of Sociolinguistic Variation. "In Stance: sociolinguistic Perspectives, edited by Alexandra Jaffe, 171-94. Oxford: Oxford University Press.

Kiesling, Scott. F. 2011. "Stance in context: Affect, alignment and investment in the analysis of stancetaking ». présenté à iMean Conference, The University of the West of England, Bristol, UK., avril 15.

Kerswill, Paul, and Ann Williams. 2000. "Creating a New Town Koine." Language in Society 29: 65-115.

Labov, William. 1966. The Social Stratification of English in New York City. Washington, DC: Center for Applied Linguistics.

- - . 1972. Language in the Inner City. Philadelphia: University of Pennsylvania Press.

Ledegen, Gudrun. 2012. "Prédicats "flottants" entre le créole acrolectal et le français à La Réunion : exploration d'une zone ambiguë ». In Changement linguistique et langues en contact : approches plurielles du domaine prédicatif, 251-70. Paris: CNRS Éditions.

Léglise, Isabelle. 2017. "Pratiques Langagières Plurilingues et Frontières de Langues." In Dessiner Les Frontières, edited by Luca Greco and Michelle Auzanneau, ENS Editions. Lyon.

Léglise, Isabelle, and Claudine Chamoreau. 2013. Eds. The Interplay of Variation and Change in Contact Settings. Amsterdam: John Benjamins.

Léglise, Isabelle, and Sophie Alby. 2016. "Plurilingual corpora and polylanguaging, when corpus linguistics meets contact linguistics", Sociolinguistic studies 10.3, 357-381.

Lipski, John M. 1984. " On the Weakening of /s/ in Latin American Spanish ». Zeitschrift für Dialektologie und Linguistik 51 (1): 31-43.

Merma Molina, Gladys. 2008. El contacto lingüístico en el español andino peruano. Estudios pragmático-cognitivos. Alicante: Publicaciones Universidad de Alicante.

Mesthrie, Rajend. 1993. "Koinéization in the Bhojpuri-Hindi Diaspora, with Special Reference to South Africa." International Journal of the Sociology of Language 99: 25-44.

Meyerhoff, Miriam, and Naomi Nagy. 2008. Eds. Social Lives in Language. Sociolinguistics and Multilingual Speech Communities. Amsterdam: John Benjamins.

Migge, Bettina. 2003. Creole Formation as Language Contact: The Case of the Surinamese Creoles. Amsterdam: John Benjamins.

- - - 2007. "Codeswitching and Social Identities in the Eastern Maroon Community of Suriname and French Guiana." Journal of Sociolinguistics 11 (1): 53-72.

Migge, Bettina, and Isabelle Léglise. 2011. "On the Emergence of New Language Varieties: The Case of the Eastern Maroon Creole in French Guiana." In Variation in the Caribbean: From Creole Continua to Individual Agency, edited by Lars Hinrichs and Joseph Farquharson, 181-99. Amsterdam: John Benjamins.

-- - 2013. Exploring Language in a Multilingual Context: Variation, Interaction and Ideology in Language Documentation. Cambridge: Cambridge University Press.

Montes Giraldo, José. 1992. « El español hablado en Colombia ». In Historia y presente del español de América, edited by César Alonso Hernández, Pabecal [Spain], 519-42. Madrid: Junta de Castilla y León. 
Mora Monroy, Siervo. 1996. « Dialectos del español de Colombia. Caracterización léxica de los sub dialectos andino-sureño y caucano-valluno ». Thesaurus : boletín del Instituto Caro y Cuervo 51 (1): 1-26.

Muntendam, Antje. 2013. " On the nature of cross-linguistic transfer: A case study of Andean Spanish ». Bilingualism: Language and Cognition 16 (01): 111-31.

Muysken, Pieter. 2000. Bilingual Speech. A Typology of Code-Mixing. Cambridge: Cambridge University Press.

Myers-Scotton, Carol. 1993. Social Motivations for Codeswitching: Evidence from Africa. Oxford, UK: Clarendon Press.

Nelson, Laury. 2008. "Le contact de langues au travail : I'étude de l'alternance codique entre les langues français-créole dans les situations de service à l'accueil direct d'EDF Guyane". Mémoire de master 2, Université Lyon 2

Nunez, Joseph Jean François, and Isabelle Léglise. 2017. "Ce que les pratiques langagières plurilingues au Sénégal disent à la linguistique de contact." In Espaces, mobilités et éducation plurilingues : éclairages d'Afrique ou d'ailleurs, edited by Michelle Auzanneau, Margaret Bento, and Malory Leclere, 99-119. Editions des archives contemporaines.

Ochs, Elinor. 1992. "Indexing Gender ». In Rethinking Context: Language as an Interactive Phenomenon, edited by Alessandro Duranti and Charles Goodwin, 335-58. Cambridge: Cambridge University Press.

Palacios Alcaine, Azucena. 2005. "La influencia del quichua en el español andino ecuatoriano ". In Variedades lingüísticas y lenguas en contacto en el mundo de habla hispana, Carmen Ferrero \& Nilsa Lasso-von Lang, 44-52. España: Bloomington-AuthorHouse.

- - . 2013. "Contact-induced change and internal evolution. Spanish in contact with Amerindien languages ". In The Interplay of Variation and Change in Contact Settings, edited by Isabelle Léglise and Claudine Chamoreau, 165-98. Studies in Language Variation. Amsterdam / Philadelphia: John Benjamins.

Paris, Julio. 1961. Gramática de la lengua quichua. Quito: Ed. Santo Domingo.

Patiño, Carlos. 2000. « Español, lenguas indígenas y lenguas criollas en Colombia ». In Sobre Etnolingüística y Otros Temas, edited by Carlos Patiño, Instituto Caro y Cuervo, 57-99. Bogotá: Imprenta Patriótica.

Pratt, Mary Louise. 1991. "Arts of the Contact Zone." Profession, 33-40.

Ramírez Espinoza, Alexander, and Almina Almira Vazquez. 2016. « Variación del fonema /s/ en contextos de juntura de palabra en el español caleño: una mirada sociolingüística1 ». Lenguaje 1 (44): 11-33.

Rampton, Ben. 1998. "Language crossing and the redefinition of reality ". In Code-switching in conversation, edited by Peter Auer, 290-317. London/New York: Routledge.

- - . 2005. Crossing: Language and Ethnicity among Adolescents. 2nd éd. Manchester, UK \& Northampton MA: St. Jerome Publishing.

Reyburn, William D. 1954. "Quechua I: Phonemics ». International Journal of American Linguistics 20 (3): 210-14.

Sánchez Moreano, Santiago. 2017 to appear. « Enoncés de type OV et positionnements sociaux dans l'espagnol parlé par les Quichuas équatoriens à Cali, Colombie ". Sociolinguistics Studies. Equinox 11 (1).

- - . 2015. « Conséquences linguistiques e identitaires du contact linguistique et dialectal à Cali (Colombie): le cas de l'ordre des constituants ». PhD dissertation, Paris: Université Paris Diderot/Sorbonne Paris Cité. https://hal.archives-ouvertes.fr/tel-01314442.

Sankoff, Gillian. 2002. "Linguistic Outcomes of Language Contact." In The Handbook of Language Variation and Change, edited by J.-K. Chambers, Peter Trudgill, and N. Schilling-Estes, 638-68. Oxford: Blackwell Publishing.

Siegel, Jeff. 1985. "Koines and Koineization." Language in Society 14: 357-78.

- - . 1987. Language Contact in a Plantation Environment. Cambridge: Cambridge University Press.

Trudgill, Peter. 1974. The Social Differentiation of English in Norwich. Cambridge: Cambridge University Press. 
Léglise I. \& Sanchez Moreano S., 2017, in Bassiouney R. (ed), Identity and Dialect Performance, Routledge, 143-159.

Vaillant, Pascal, and Isabelle Léglise. 2014. "A la croisée des langues : Annotation et fouille de corpus plurilingues." Revue des Nouvelles Technologies de I'Information RNTI-SHS-2: 81-100.

Vertovec, Steven. 2007. « New Directions in the Anthropology of Migration and Multiculturalism ». Ethnic and Racial Studies 30 (6): 961-78.

- - . 2010. "Towards Post-Multiculturalism? Changing Communities, Conditions and Contexts of Diversity ». ISSJ International Social Science Journal 61 (199): 83-95.

Wurm, Stephen A. 1996. Atlas des langues en péril dans le monde. Paris: UNESCO. 